УДК 351:330.3

DOI https://doi.org/10.32838/TNU-2663-6468/2020.3/13

\title{
Буканов Г.М.
}

Дніпропетровський регіональний інститут державного управління

Національної академії державного управління при Президентові України

\section{КОНЦЕПЦІЯ СТАЛОГО РОЗВИТКУ ЯК ОСНОВА ФОРМУВАННЯ ДЕРЖАВНОЇ ЕКОЛОГІЧНОЇ ПОЛІТИКИ НА ДЕРЖАВНОМУ ТА РЕГІОНАЛЬНОМУ РІВНЯХ}

\begin{abstract}
У статті проаналізовано концепцію сталого (збалансованого) розвитку як основи формування і реалізації екологічної політики на державному і регіональному рівнях. Державна екологічна політика має визначення системи політичних, економічних, юридичних та інших заходів, які вжиті державою для управління екологічною ситуачією, а також для забезпечення рачіонального використання природних ресурсів на території Украӥни з метою забезпечення гармонійного та збалансованого розвитку економіки, суспільства і природи. Доведено, що основою стратегії сталого розвитку Украӥни є орієнтація системи державного управління на децентралізацію і сталий розвиток регіонів у соиіальному, економічному та екологічному аспектах як окремих соціально-еколого-економічних систем. Сталий розвиток передбачає збалансований розвиток, спрямований на задоволення потреб суспільства у соиіальній, економічній та екологічній сферах на загальноцивілізаційному, державному та регіональному рівнях. Звідси маємо три основні складники сталого розвитку - соиіальний, економічний $i$ екологічний. Тому сталий розвиток передбачає свідоме формування збалансованих відносин між економічним зростанням (економічний складник), турботою про навколишнє середовище (екологічний складник) та здоров'ям людини (сочіальний складник).
\end{abstract}

Визначено, що в межах сочіально-еколого-економічної системи, що відповідас певному адміністративно-територіальному утворенню (регіону), може реалізовуватися програма сталого розвитку, яка відображена як у державній екологічній політииі, так і у регіональній екологічній політииі, а отже, саме державне управління покликане забезпечувати належні інституиійні умови щодо ризикостійкого розвитку соиіально-еколого-економічної системи. Ця система визначена як територія, на якій у необхідному поєднанні функиіонують екологічні, економічні й соиіальні системи на основі спільного використання природних і виробничих ресурсів. Регіональний рівень може відображати глобальний (міжнародний) рівень, а державна екологічна політика (загальноначіональний рівень) зосереджена у регіональній і місиевій екологічній політиці (регіональний рівень), тому державне управління забезпечує інституиійні умови щэодо сталого (збалансованого) розвитку сочіально-еколого-економічної системи.

Ключові слова: збалансований розвиток, стратегія, ресурси, регіон, сочіально-екологоекономічна система, «зелена» економіка.

Постановка проблеми. Усвідомлення людством реальної небезпеки екологічної катастрофи, яка загрожує існуванню цивілізації, спонукало до розробки нової концепції сучасного розвитку. Як нова парадигма розглядається сталий розвиток, який доцільно розуміти не лише в контексті зміни стосунків людини і довкілля задля розширення економічного зростання, а і як скоординовану глобальну стратегію виживання людства, орієнтовану на збереження і відновлення природних спільнот у масштабах, необхідних для повернення до меж господарської ємності біосфери. Поява парадигми сталого розвитку, в основі якої лежить збалансування економічного, соціального й екологічного складників та відповідальність суспільства не лише в своїх межах, але й перед наступними поколіннями, вплинула на формування нової стратегії екологічної політики на державному і регіональному рівнях.

Аналіз останніх досліджень і публікацій. Проблемам, становленню та дослідженню реалізації екологічної політики в Україні присвячено роботи відомих науковців та фахівців, таких як: В. Андронов, Г. Білявський, Ю. Боковикова, О. Веклич, Д. Ветвицький, Л. Жарова, Н. Коваль, Н. Малиш, Л. Мельник, Л. Стасюк, В. Шевчук, Л. Якушенко, Л. Яценко та ін. Концептуальні положення і принципи сталого розвитку досліджували вітчизняні вчені, такі як: А. Балашов, С. Домбровська, В. Загорський, Н. Караєва, В. Коврегін, О. Колєнов, В. Кучерявий, Т. Перга, А. Помаза-Пономаренко, 
I. Сегеда, Ф. Стольберг, О. Чернікова та інші. Проте низка питань досі залишаються малодослідженими, зокрема не досить висвітлено проблему формування регіональної екологічної політики на основі концепції сталого розвитку.

Метою статті $\epsilon$ аналіз концепції сталого розвитку як основи формування і реалізації екологічної політики на державному і регіональному рівнях.

Виклад основного матеріалу дослідження. Екологічна політика і їі формування та реалізація нині виступає як базовий складник сучасних соціально-еколого-економічних систем, визначаючи перспективи їх сталого розвитку. В українському законодавстві державна екологічна політика визначається як «система специфічних політичних, економічних, юридичних та інших заходів, що вживаються державою для управління екологічною ситуацією, забезпечення раціонального використання природних ресурсів на території України та забезпечення гармонійного, динамічно збалансованого розвитку економіки, суспільства, природи» [10, с. 12]. А в прийнятому Законі України «Про основні засади (стратегіi) державної екологічної політики України на період до 2030 року» метою екологічної політики є досягнення задовільного стану навколишнього середовища шляхом впровадження екосистемного підходу у всі напрями соціально-економічного розвитку України з метою забезпечення конституційного права кожного громадянина України на безпечне навколишнє середовище, впровадження збалансованого природокористування, збереження і відтворення природних екосистем [7].

Методологічною основою формування державної екологічної політики та їі управління виступає концепція сталого (збалансованого) розвитку, на основі якої формуються пріоритети соціального, економічного та екологічного розвитку як у глобальному, так і локальному вимірах.

У 1987 році за результатами роботи Коміciï Г. Брундтланд була опублікована доповідь «Наше спільне майбутнє» ("Our common future”), в якій і була представлена нова концепція сталого (збалансованого) розвитку як альтернатива розвитку, що базується на необмеженому економічному зростанні [2].

Спираючись на визначення Комісії ООН та науковий аналіз, Г. Дейлі чітко характеризує термін «сталий розвиток» як значення гармонійного, збалансованого, безконфліктного прогресу всієї земної цивілізації, груп країн (регіонів, субрегіонів), а також окремо взятих країн нашої планети за науково обгрунтованими планами (методами системного підходу), коли в процесі неухильного інноваційного інтенсивного (а не екстенсивного) економічного розвитку країн одночасно позитивно вирішується комплекс питань щодо збереження довкілля, ліквідації експлуатації, бідності та дискримінації як кожної окремо взятої людини, так і цілих народів чи груп населення, у тому числі за етнічними, расовими чи статевими ознаками [9].

3. Герасимчук визначила сталий розвиток як процес забезпечення функціонування територіальної системи із заданими параметрами в певних умовах протягом необхідного проміжку часу, що веде до гармонізації факторів виробництва та підвищення якості життя сучасних і наступних поколінь за умови збереження і поетапного відтворення цілісності навколишнього середовища $[12$, с. 9$]$.

Загалом, на міжнародному рівні (в нормативноправовому аспекті) концепція сталого розвитку пройшла значний період свого становлення і удосконалення [8, с. 10-11]: 1) 1972 р. - Стокгольмська конференція ООН з питань навколишнього середовища, де представники 113 країн провели першу зустріч на вищому рівні для обговорення екологічних проблем; 2) 1983 р. - створення ООН Всесвітньої комісії з навколишнього середовища і розвитку (комісія Г. Брундтланд); 3) 1987 р. - доповідь Комісії Г. Брундтланд «Наше спільне майбутнє», у якій були сформульовані попередження про необхідність зміни способу життя і діяльності, щоб запобігти подальшому погіршенню стану навколишнього середовища; 4) 1992 р. - ідеї сталого розвитку були офіційно проголошені на Міжнародній конференції 3 навколишнього середовища і розвитку у Ріо-деЖанейро (Самміт Землі) United Nations Conference on Environment and Development (Earth Summit), Rio de Janeiro. Ця конференція розглядала навколишне середовище і соціально-економічний розвиток як взаємопов'язані і взаємозалежні галузі. На форумі прийнято рішення про розробку нових міжнародних стандартів у сфері соціально-еколого-орієнтованого управління; 5) 1994 р. - проведення глобального екологічного форуму «Міста і сталий розвиток» (Манчестер, Велика Британія). Демонстрація перших «Програм сталого розвитку» великих міст світу. Проведення конференції «Довкілля і здоров'я» в Гельсінкі (Фінляндія); 6) 1996 р. - проведення глобального екологічного форуму "Habitat - II" (Навколишнє середовище) (Стамбул, Туреччина); 7) 1997 р. - підбиття перших підсумків «Ріо - 92» на Нараді «Ріо + 5»; 8) 1998 р. - форум за підтримки $\mathrm{OOH}$ «Здорове середовище міста» (Мадрид, Іспанія); 9) 1999 р. - глобальний форум «Здорова планета» (Лондон, Велика Британія); 10) 2000 р. - Саміт 
Тисячоліття ООН, на якому 189 держав світу, у тому числі й Україна, затвердили Декларацію Тисячоліття ООН та прийняли зобов'язання досягти Цілей розвитку тисячоліття до 2015 року. Однією з Цілей $\epsilon$ забезпечення сталого екологічного розвитку (Ціль 7); 11) 2002 р. - Всесвітня зустріч на вищому рівні зі сталого розвитку у Йоганнесбурзі (ЮАР), результатом якої стала Йоганнесбурзька Декларація зі сталого розвитку та план дій; 12) 2012 р. - Конференція ООН зі сталого розвитку «Ріо+20», на якій були обговорені проблеми «зеленої економіки», сталого розвитку та подолання бідності; 13) 2015 р. - Саміт зі сталого розвитку (Нью-Йорк, США), на якому було схвалено план дій на період після 2015 року, що включає 17 глобальних Цілей та 169 завдань зі сталого розвитку. Нові Цілі та завдання мають комплексний характер і забезпечують збалансованість усіх трьох компонентів сталого розвитку: економічного, соціального та екологічного.

Таким чином, сталий розвиток передбачає збалансований розвиток, спрямований на задоволення потреб сучасного покоління без шкоди для майбутнього у соціальній, економічній та екологічній сферах суспільства на загальноцивілізаційному, державному і регіональному рівнях. Звідси маємо три основні складники сталого розвитку соціальний, економічний і екологічний.

Економічний складник грунтується на вимогах збереження та розвитку сукупного капіталу, за допомогою якого забезпечується створення необхідних для суспільства та індивіда ресурсів у вигляді сукупного соціального доходу, що досягається за рахунок раціонального використання природних ресурсів, енерго- та ресурсоефективних технологій, включаючи видобуток і переробку сировини, технології більш чистого виробництва, виробництва екологічно вигідної продукції, мінімізацію і максимальну переробку відходів.

Сталий розвиток орієнтований на людину i спрямований на збереження стабільності соціальних і культурних систем. Як зазначає А. Балашов, «для досягнення сталого розвитку необхідно створити більш ефективну управлінську систему, що враховує історичний досвід, заохочує плюралізм і орієнтується на людину як суб'єкт розвитку. Спираючись на розширення варіантів вибору людини як головну цінність, концепція сталого розвитку націлює на впровадження принципу участі кожного індивіда в процесах, які формують сферу його життєдіяльності» [1].

На основі резолюції Генеральної Асамблеї Організації Об'єднаних Націй від 25 вересня 2015 року № 70/1 проголошені глобальні цілі сталого розви- тку до 2030 року та результати їх адаптації з урахуванням специфіки розвитку України, що викладені у Національній доповіді «Цілі сталого розвитку: Україна», було видано указ Президента України щодо забезпечення дотримання Цілей сталого розвитку України на період до 2030 року [13].

Стратегічне бачення сталого розвитку України грунтується на забезпеченні національних інтересів та виконанні міжнародних зобов'язань України щодо переходу до сталого розвитку. Такий розвиток передбачає [11]: подолання дисбалансів в економічній, соціальній та екологічній сферах; трансформацію економічної діяльності, перехід на засади «зеленої економіки»; побудову мирного та безпечного, соціально згуртованого суспільства 3 належним врядуванням та інклюзивними інституціями; забезпечення партнерської взаємодії органів державної влади, органів місцевого самоврядування, бізнесу, науки, освіти та організацій громадянського суспільства; повну зайнятість населення; високий рівень науки, освіти та охорони здоров'я; підтримання довкілля в належному стані, який забезпечуватиме якісне життя та благополуччя теперішнього і майбутніх поколінь; децентралізацію та впровадження регіональної політики, яка передбачає гармонійне поєднання загальнонаціональних i регіональних інтересів; збереження національних культурних цінностей і традицій.

Отже, стратегія сталого розвитку України передбачає таке: 1) у соціальній сфері - здоров'я, освіту, зайнятість, добробут, соціальну справедливість, забезпечення потреб у чистому довкіллі; 2) в економічній сфері - «зелену економіку», підтримку ресурсо- та енергозберігаючого виробництва, інноваційних технологій тощо; 3) в екологічній сфері боротьбу зі зміною клімату, збереження морських, водних екосистем і екосистем суші тощо. Основою Стратегії сталого розвитку України є орієнтація системи державного управління на децентралізацію і сталий розвиток регіонів у соціальному, економічному та екологічному аспектах як окремих соціально-еколого-економічних систем.

Ученим Б. Буркинським соціально-екологоекономічна система визначається як територія, на якій у необхідному поєднанні функціонують екологічні, економічні й соціальні системи на основі спільного використання природних і виробничих ресурсів [3]. У деяких наукових розробках цього автора також підкреслюється територіальний аспект, однак соціально-еколого-економічна система ним розглядається як взаємодія природних та господарських територіальних комплексів у процесі природокористування [4]. 
Іншими теоретиками та практиками (М. Згуровскі, В. Макдонован та ін.) також звертається увага на взаємоз' язок і взаємозалежність економічного та природно-ресурсного територіальних компонентів як системоутворюючої ознаки [14].

С. Домбровська, В. Коврегін, А. Помаза-Пономаренко, О. Колєнов під терміном «соціальноеколого-економічна система» розуміють цілісне (інтеграційне) утворення, що поєднує економічну, соціальну, інституційну й екологічну підсистеми, які взаємодіють через обмінні процеси між людською діяльністю та довкіллям [5, с. 10-11].

Дослідник В. Загорський основними ознаками соціально-еколого-економічної системи виділяє такі як: 1) територія, що відрізняється від інших сукупністю природних або історично сформованих економіко-географічних особливостей; 2) просторовоорганізована форма життєдіяльності населення, що враховує сфери проживання, професійно-трудової діяльності, керована з єдиного політико-адміністративного центру і поєднувана реальними і різноманітними зв'язками (виробничо-трудовими, політичними, соціально-економічними, етнічними, культурно-побутовими) на основі самоврядування i повної реалізації своїх прав як суб'єкта соціальнополітичного життя; 3) велика таксономічна одиниця виробничо-територіального устрою країни і форма організації виробничо-суспільного життя населення; 4) територія в адміністративних межах держави, що характеризується такими основними рисами: комплексністю, цілісністю, спеціалізацією і керованістю [6, с. 87-88].

Таким чином, у межах соціально-еколого-економічної системи, що відповідає певному адміністративно-територіальному утворенню (регіону), може реалізовуватися програма сталого розвитку, яка відображена як у державній екологічній політиці, так і у регіональній екологічній політиці, а отже, саме державне управління покликане забезпечувати належні інституційні умови щодо ризикостійкого розвитку соціально-еколого-економічної системи регіону.

На рис. 1 представлена схема реалізації концепції сталого розвитку.

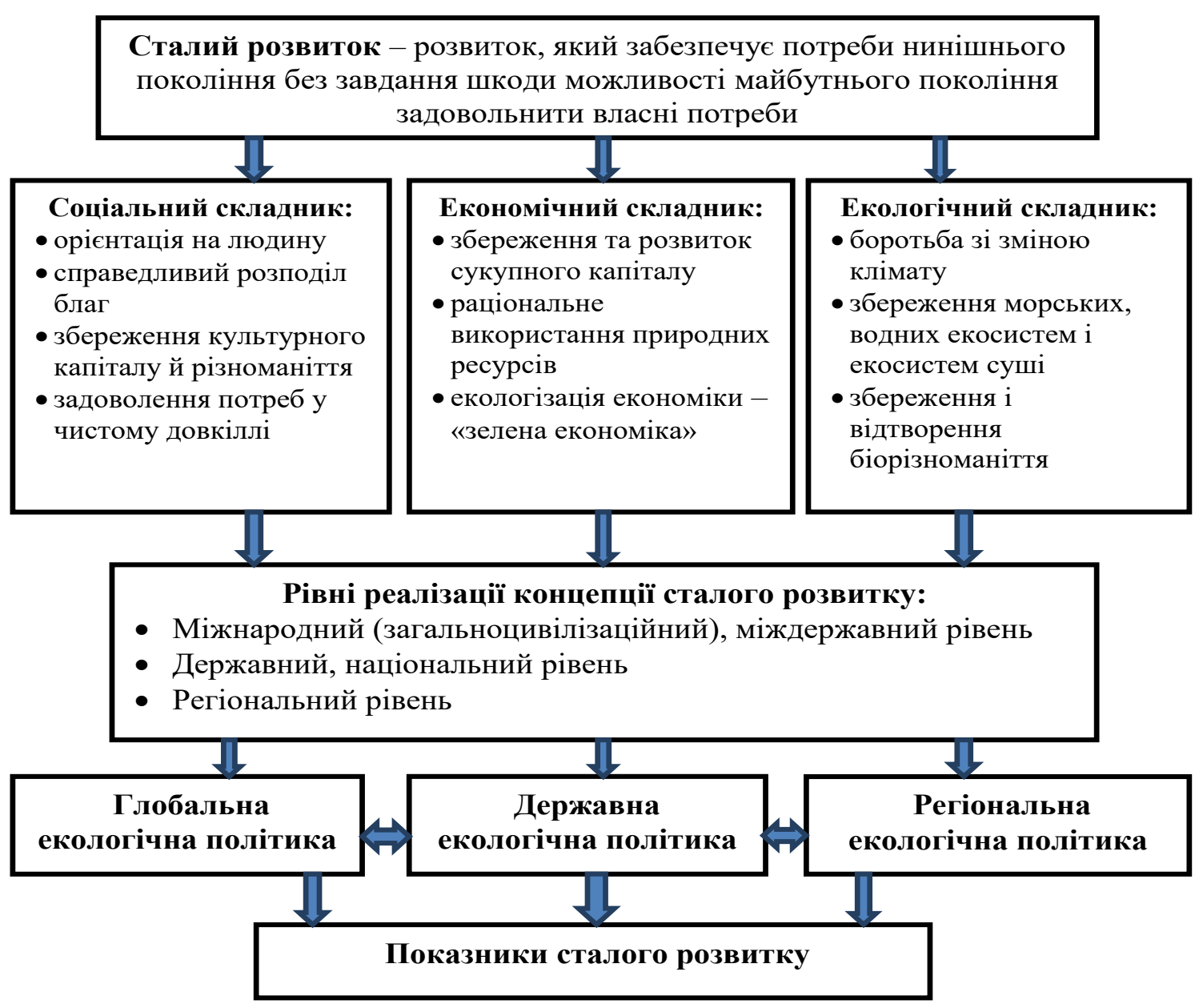

Рис. 1. Модель реалізації концепції сталого розвитку як основи формування екологічної політики на глобальному, державному і регіональному рівнях 
Висновки. Визначено, що методологічною основою формування державної екологічної політики та її управління виступає концепція сталого (збалансованого) розвитку, яка передбачає свідоме формування збалансованих відносин між економічним зростанням (економічний складник), турботою про навколишнє середовище (екологічний складник) та здоров'ям людини (соціальний складник). Регіон являє собою відкриту соціально-еколого-економічну систему з певними кордонами, в межах якої взаємодіють iï підсистеми, що характеризуються специфічними ознаками та системною організацією, причому соціально-еколого-економічна система являє собою цілісне (інтеграційне) утворення, що поєднує економічну, соціальну, інституційну й екологічну підсистеми. Таким чином, на регіональному рівні може реалізовуватися програма сталого розвитку, яка відображена у глобальній екологічній політиці (міжнародний рівень), у державній екологічній політиці (загальнонаціональний рівень), у регіональній і місцевій екологічній політиці (регіональний рівень), а отже, саме державне управління покликане забезпечувати належні інституційні умови щодо сталого (збалансованого) розвитку соціально-еколого-економічної системи.

Перспективним напрямом подальших досліджень $€$ визначення рівнів, принципів і функцій державного управління у сфері формування і реалізації екологічної політики у регіонах.

\section{Список літератури:}

1. Балашов А. Концепція сталого розвитку в глобальному вимірі та iï управлінська операціоналізація. Державне управління та місиеве самоврядування. 2009. Вип. 3(3). URL: http://www.nbuv.gov.ua/portal/ Soc_Gum/Dums/2009_3/index.html/.

2. Бондар O.I., Хоренжая I.В., Хоренжая А.О. Екологічна безпека та сталий розвиток - основоположні аспекти екологічної політики. Збірник наукових прачь СНУЯЕ та П. URL: http://www.nbuv.gov.ua/portal/ natural/znpsnu/2010_3/Z35R2S2.pdf.

3. Буркинский Б.В. Экологизация политики регионального развития. Одесса : Институт проблем рынка и экономико-экологических исследований НАН Украины, 2002. 328 с.

4. Буркинський Б., Галушкіна Т. Глобалізація економіки та національна екологічна доктрина. Економіст. 2002. № 9. С. 20-23.

5. Домбровська С.М., Коврегін В.В., Помаза-Пономаренко А.Л., Колєнов О.М. Державне управління у сфері безпеки соціально-еколого-економічних систем : монографія. Харків : НУЦЗУ, 2017. 244 с.

6. Загорський В.С. Концептуальні основи формування системи управління сталим розвитком екологоекономічних систем : монографія. Львів : ЛРІДУ НАДУ, 2018. 336 с.

7. Закон України «Про основні засади (стратегії) державної екологічної політики України на період до 2030 року. Вісник Верховної Ради Украӥни. 2019. № 16. Ст. 70. URL: https://zakon.rada.gov.ua/laws/ show/2697-19?lang=uk

8. На шляху зеленої модернізації економіки: модель сталого споживання та виробництва: дов. / С.В. Берзіна та ін. Київ : Інститут екологічного управління та збалансованого природокористування, 2017. 138 с.

9. Національна парадигма сталого розвитку України / за заг. ред. академіка НАН України Б.С. Патона. Київ : Державна установа «Інститут економіки природокористування та сталого розвитку Національної академії наук України», 2012. 72 с.

10. Про Основні засади (стратегію) державної екологічної політики України на період до 2020 року : Закон України від 21 груд. 2010 р. № 2818-VI. URL: http://zakon5.rada.gov.ua/laws/show/2818-17/page.

11. Проєкт Закону України «Про Стратегію сталого розвитку України до 2030 року». Ліга Закон. URL: http://search.ligazakon.ua/1_doc2.nsf/link1/JH6YF00A.html.

12. Стольберг Ф.В., Чернікова О.Ю. Конспект лекцій з навчальної дисципліни «Стратегія сталого розвитку». Харків : ХНАМГ, 2011. 91 с.

13. Указ Президента України № 722/2019 «Про Цілі сталого розвитку України на період до 2030 року». / Президент України. Офіційне інтернет-представництво. URL: https://www.president.gov.ua/ documents/7222019-29825.

14. Zgurovsky M. Sustainable development analysis - global and regional contexts. P.1. Global analysis of quality and security of life. Kyiv : NTUU "KPI”, 2010. 184 p.

\section{Bukanov G.M. THE CONCEPT OF SUSTAINABLE DEVELOPMENT AS A BASIS FOR THE FORMATION OF STATE ENVIRONMENTAL POLICY AT THE STATE AND REGIONAL LEVELS}

The article analyzes the concept of sustainable development as a basis for the formation and implementation of environmental policy at the state and regional levels. State environmental policy defines a system of political, 
economic, legal and other measures taken by the state to manage the environmental situation, as well as to ensure the rational use of natural resources in Ukraine to ensure harmonious and balanced development of the economy, society and nature. It is proved that the basis of the strategy of sustainable development of Ukraine is the orientation of the public administration system on decentralization and sustainable development of regions in social, economic and environmental aspects as separate socio-ecological-economic systems. Sustainable development involves balanced development aimed at meeting the needs of society in the social, economic and environmental spheres at the general civilizational, state and regional levels. From here we have three main components of sustainable development - social, economic and environmental. Therefore, sustainable development involves the conscious formation of a balanced relationship between economic growth (economic component), care for the environment (environmental component) and human health (social component). It is determined that within the socio-ecological-economic system, which corresponds to a certain administrativeterritorial formation (region), a program of sustainable development can be implemented, which is reflected in both state environmental policy and regional environmental policy, and therefore public administration designed to provide appropriate institutional conditions for risk-sustainable development of the socioecological and economic system. This system is defined as an area in which the necessary combination of ecological, economic and social systems based on the joint use of natural and productive resources. The regional level can reflect the global (international), state environmental policy (national level) concentrated in regional and local environmental policy (regional level), and therefore, public administration provides institutional conditions for sustainable (balanced) development of socio-ecological-economic system.

Key words: balanced development, strategy, resources, region, socio-ecological-economic system, "green" economy. 